\title{
Getting Ready for a Post-Work Future
}

\author{
Andy Hines \\ Assistant Professor and Program Coordinator, Foresight, ahines@uh.edu \\ University of Houston, 4235 Cullen Boulevard Room 110 Houston, TX 77204, USA
}

\begin{abstract}
$\mathrm{M}$ ainstream policy and scientific debates on the future of labor markets are dominated by the "next job title" approach. We propose changing this framework by examining the plausibility of a future vision that eliminates the needs for jobs as such. The article describes major drivers pushing toward a post-work future that are already underway, such as the rise of automation and artificial intelligence, shifts in individual values, and blurring the line between daily life activities. There are also
\end{abstract}

Abstract

Keywords: Future; foresight; work; vision; skills; jobs; postwork; capitalism; automation; planning significant obstacles to a post-work future, related to the current central role of work in one's social life. Even though these obstacles are being addressed it may take decades for this transition to occur. Despite this, in order to overcome related challenges it makes sense to already begin preparing for the transition. In particular, we advocate for a serious policy discussion on the post-work future, the development of programs to manage the transition and promotion the value of purpose and personal futures planning.

Citation: Hines A. (2019) Getting Ready for a Post-Work Future. Foresight and STI Governance, vol. 13, no 1, pp. 19-30. DOI: 10.17323/2500-2597.2019.1.19.30 


\section{Introduction and Research Methodology}

Futurists and experts are often asked to produce a list of future job titles [Talwar, Hancock, 2010; Frey, 2011; Armstrong, 2017; Slayter, 2019]. One looks for emerging trends and industries and thinks about its capabilities and applications as well as the role people can play. In biotech, there may be genetic counselors or baby designers, in climate science, there may be weather modification engineers, or in space there may be meteorite miners or terraformers. Previous work listed job titles such as career change counselor, farm manager, genome specialist, man-machine interface specialist, space flight supervisor, and robot guides [Hines, 1993; 1996]. These are useful and entertaining exercises, though perhaps more of the latter than the former.

This piece goes beyond the "next job title" approach to explore the role of jobs in the longer-term future. The argument is that jobs will increasingly lose their position of playing the dominant role in most people's daily life. The current piece draws most heavily upon three separate but related research streams: (1) an upcoming book on visions of the future that might follow the current dominant capitalist system ${ }^{1}$ (2) an extensive study of emerging student needs for the Lumina Foundation that explored the role of job preparation for universities in the future ${ }^{2}$, and (3) a recently completed study on the future of work in 2050 for the NASA Langley Research Center ${ }^{3}$ that included scenarios of a post-work future. Several steps from the core "framework foresight approach", designed with the author's input, were used in developing this paper (see table 1) [Hines \& Bishop, 2013; Hines et al., 2018].

\section{A Plausible Future without Jobs}

It may be several decades away, but research suggests that a world without jobs (or post-work) is a plausible future [Houston Foresight, 2017]. It is not suggested that this is inevitable, but rather that it is plausible enough to be worth planning for today. There is already considerable discussion about the potential role of automation and AI in eliminating jobs. Long-term value shifts suggest less importance placed upon jobs and students may also be increasingly less focused on obtaining a job as the key reason for pursuing a higher education. The concept of Universal Basic Income ${ }^{4}$ has moved from the fringes to the mainstream as a consideration in dealing with job loss [Bergstein, 2018; Brown, 2018; De Wispelaere et al., 2018; Standing, 2018]. A Google Trends search on "universal basic income" going back to 2014 and 2015 rarely exceeds 10 searches per week; by 2016 and 2017 this number grew to between 25 and 50 searches weekly; and has now been routinely exceeding 50 since 2018 . There have been referenda [Minder, 2016] trials [Anzilotti, 2019] and it has recently been a policy platform for a US presidential candidate [Diamond, 2019].

Projecting these developments forward, it is reasonable to consider a long-term future where having a paid job is no longer the key determinant for one's access to resources or more plainly the key to one to being able to make a living. This shift is on the order of magnitude described by Toffler [Toffler, 1980] in his three waves: from agriculture to industrial to post-industrial/information societies. It is useful to note that in agricultural societies and huntergatherer societies before that most people did not have jobs and go to work. But work they did! Jobs are a relatively recent development in human history, beginning in Toffler's industrial wave and continuing through today's post-industrial/information wave [Slaughter et al., 2016]

The research supporting the plausibility of a post-work future emerged from a 2012 "After Capitalism" conference organized by the Houston Foresight program to explore ideas about the next economic system [Hines, 2013]. An informal horizon scanning [Hines et al., 2018] project was launched and blogs for books, reports, articles, and so on that purported to talk about the next economic system. When three dozen "next economy" concepts had been identified a few years ago, it was decided to research the topic more thoroughly and write a book (in progress). Forty-seven concepts were ultimately identified. However, almost half of these were rooted in the current economic system with some new features. That left twenty-three concepts that were classified as visions (or components of a vision) focused on a new economic order. These visions are organized into three themes-Tech-Led Abundance, Non-Workers' Paradise, and the Sustainable Commons (Figure 1, Table 2).

The relevant point for this paper is that in each of these visions, paid work is no longer a central organizing socioeconomic principle. In Tech-Led Abundance, the rapidly accelerating development of automation/AI/robotics, biotech, nanotech, and other technologies have created an abundance of wealth such that people no longer need to work. In the Non-Workers Paradise, the political struggle over inequality that favors new organizing principles such as Universal Basic Income begins. Finally, in the Sustainable Commons, there is work to be done, but it is managed as a commons rather than organized as paid work.

It is beyond the scope of this paper to dig into the details of these visions. They suggest that a different economic/ work/jobs paradigm is plausible, one that is no longer organized around paid full-time jobs.

\footnotetext{
1 The outcomes of this research will be summarized in a forthcoming book. For more details see: https://www.andyhinesight.com/category/after-capitalism/, last accessed 02.03.2019.

2 See: https://www.luminafoundation.org/future-of-student-needs, last accessed 02.03.2019.

${ }^{3}$ See: https://www.nasa.gov/offices/ocio/ittalk/7-2011_LaRC_2050.html, last accessed 02.03.2019.

${ }^{4}$ Defined by the Basic Income Earth Network as "a periodic cash payment unconditionally delivered to all on an individual basis, without a means-test or work requirement."
} 


\section{Table 1. Research tools}

\begin{tabular}{|l|l|}
\hline \multicolumn{1}{|c|}{ Method } & \multicolumn{1}{c|}{ Notes } \\
\hline Horizon scanning & $\begin{array}{l}\text { The foundation of the research is horizon scanning, a foresight tool for identifying "signals of change". } \\
\text { Previously developed scanning libraries on the future of work were reviewed, and new scanning was } \\
\text { undertaken as well. }\end{array}$ \\
\hline Driver identification & $\begin{array}{l}\text { Drivers are thematic clusters of related changes identified from the research - literature review and trend } \\
\text { analysis -- and horizon scanning that are influencing or shaping significant change. }\end{array}$ \\
\hline Obstacle identification & $\begin{array}{l}\text { This is an optional step in the Framework Foresight process that was judged to be particularly useful to this } \\
\text { paper in order to provide a balanced account of the potential transition to the proposed visions. }\end{array}$ \\
\hline Visioning & $\begin{array}{l}\text { The three potentially transformative visions were identified from a cluster analysis of concepts of roughly five } \\
\text { dozen concepts (mostly books; some reports) of a future beyond capitalism. }\end{array}$ \\
\hline Implications analysis & This step outlines recommendations on what to do to address the research question moving forward. \\
\hline Source: author. & \multicolumn{2}{|l}{} \\
\hline
\end{tabular}

\section{The Transition is Underway}

It may be tempting to relax and not be overly concerned since these visions may be "several decades away." However, the transition is already underway. Several dozen of concepts that are considered potentially transformative future visions were analyzed for common underlying drivers suggesting their viability. The entries in the scanning library were similarly reviewed and analyzed. A third approach to identifying drivers entailed a review of the author's previous publications focused on the future of work. This analysis produced a long list of drivers that were synthesized into seven considered for this paper: changing values, lifestyle shifts, technology acceleration (AI/machine intelligence), automation, economic growth, environment and carrying capacity, and political paralysis. Given that the objective of the paper was to see whether a plausible case could be made for the post-work future, it was not deemed necessary to make a detailed and comprehensive case, but rather explore a representative sub-set of the drivers to make a reasonably sufficient case. Thus the following three key drivers supporting a post-work future are identified and briefly characterized:

- The rise of automation, AI, machine intelligence (combines automation and technology acceleration)

- Shifts in individual values

- Blurring of the lines distinguishing various types of daily life activities (characterizes lifestyle shifts).

\section{Rise of Automation, AI, and Machine Intelligence}

The relentless growth of processing power is enabling various IT applications to become increasingly formidable competitors for jobs. Supporters of the "Singularity" concept [Kurzweil, 2005] and several prominent AI experts suggest that within the next few decades machine intelligence will surpass human intelligence [Galeon, 2018]. Singularity advocates and transhumanists suggest that humans will effectively need to merge with machines via augmentation to keep up [Greene, 2017; Vita-More, 2018]. In The Second Machine Age, Brynjolfsson and McAfee [Brynjolfsson, McAfee, 2014] acknowledge that position but also suggest a future in which humans remain relevant to the economy and jobs, as the economy creates more new jobs than are replaced by automation. Concern about the impact of AI/automation upon jobs was triggered in 2013 by a paper from the Oxford Martin school estimating that $47 \%$ of US jobs are at risk of automation [Frey, Osborne, 2013].The controversy over whether AI/automation will create or destroy more jobs continues. Technology proponents, such as Reese [Reese, 2019] suggest that "AI will create millions of jobs that are far beyond our ability to imagine. Prominent organizations, such as the IT consultancy Gartner and the World Economic Forum argue that more jobs will be created, at least in the short term [Thorpe, 2018; Leopold et al., 2018]. In either case, Brynjolfsson and McAfee [Brynjolfsson, McAfee, 2014] suggest that "technological progress is going to leave behind some people, perhaps even a lot of people. The "perhaps" softens it a bit, but the statement is pretty clear.

It is reasonable to see how $\mathrm{AI} /$ automation/machines bring about a great productive bounty, but the impact upon jobs is a more challenging question. Bostrom [Bostrom, $2014,22]$ suggests the possibility of super-intelligent AI with an "intellect that greatly exceeds the cognitive per-

\section{Figure 1. After Capitalism Visions}

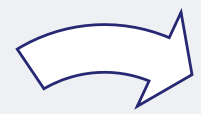

Sustainable

Tech-led

Commons

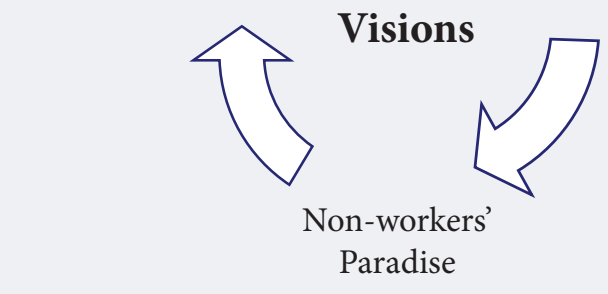

Abundance

Source: author 
Table 2. Short description of After Capitalism Visions

\begin{tabular}{|l|l|l|}
\hline \multicolumn{1}{|c|}{ Vision } & \multicolumn{1}{|c|}{ Description } & \multicolumn{1}{c|}{ Sources } \\
\hline Tech-led Abundance & $\begin{array}{l}\text { The core of these concepts is that accelerating, exponential growth } \\
\text { in technological capabilities will so dramatically boost productivity } \\
\text { that it will create an abundances of wealth and solve the world's } \\
\text { problems }\end{array}$ & $\begin{array}{l}\text { [Kurzweil, 2005; Diamandis, 2012; More, } \\
\text { 2013; Bostrom, 2014; Rifkin, 2014] }\end{array}$ \\
\hline $\begin{array}{l}\text { Non-workers' } \\
\text { Paradise }\end{array}$ & $\begin{array}{l}\text { This play on the historical notion of "worker's paradise" focuses on } \\
\text { concepts involving the political struggle for a "post-work" world }\end{array}$ & $\begin{array}{l}\text { [Schweickart, 2011; Standing, 2014; Ma- } \\
\text { son, 2015; Frase, 2016; Srnicek, Williams, } \\
\text { 2016; Loh, Jimenez, 2017] }\end{array}$ \\
\hline $\begin{array}{l}\text { Sustainable } \\
\text { Commons }\end{array}$ & $\begin{array}{l}\text { These concepts sort into environmentally-inclined, morality-based, } \\
\text { or purpose-driven, along the lines of it being humanity's moral } \\
\text { obligation to create a more sustainable future. Also within this } \\
\text { cluster were several concepts exploring the potential for a commons } \\
\text { or commoning approach to enable the sustainable future }\end{array}$ & $\begin{array}{l}\text { [Alperovitz, 2013; CASSE, n. d.; WCED, } \\
\text { 1987; Jackson, 2009; Eisenstein, 2011; } \\
\text { Haque, 2011; EMF, 2013; Scharmer, 2013; } \\
\text { Boltier, 2014; Kallis et al., 2015; Fiora- } \\
\text { monti, 2016; De Angelis, 2017]. }\end{array}$ \\
\hline Source: compiled by the author with reliance on the listed sources. & \multicolumn{2}{|l}{} \\
\hline
\end{tabular}

formance of humans in virtually all domains of interest. The potential for the benefits accruing to those owning the technology could contribute to even greater economic inequality in the future. [Sherman, 2018; Snow, 2018]. Brynjolfsson and McAfee [Brynjolfsson, McAfee, 2014] suggest that superstars will fare very well at the expense of everyone else. The top $20 \%$ of knowledge worker elites will do fine (but nowhere near as well as the superstars). Mostly everyone else struggles. For instance, automated vehicles, in addition to making profits for the auto industry, could provide greatly improved traffic safety and reduce congestion. However, they could also lead to unemployment for ridesharing drivers and truck drivers [Gibbs, 2017; Groshen et al., 2018].

It is a plausible, though not inevitable, scenario that AI/ automation could lead to net job loss as well as exacerbate economic inequality that in turn would put further pressure on the current approach of jobs providing one's primary means to make a living.

\section{Shifts in Values}

Data from the World Values Survey ${ }^{5}$ suggests that individual values have been developing in a consistent direction over the long term. Inglehart [Inglehart, 2018], founder of the World Values Survey, observes that "people's values and behavior are shaped by the degree to which survival is secure." He notes that unprecedentedly high levels of economic and physical security since World War II have enabled a shift from materialist to post-materialist values (referred to as postmodern in this article) [Inglehart, 2018]. Estimates suggest that about $25 \%-30 \%$ of people in affluent countries today embrace postmodern values and that emerging markets will move in that direction, but perhaps a generation later (Figure 2 summarizes the four types of values) [Hines, 2011]. As people with postmodern and integral values increasingly dominate leadership roles and move from the margins to the mainstream, their priorities will create a different landscape that will in turn shape views about jobs [Hines, 2011].
The long-term shift is from left to right in Figure 2: from traditional to modern to postmodern to integral. The percentage estimates below are derived from the World Values Survey data, Spiral Dynamics [Beck \& Cowan, 2006], and work by Ray and Anderson on the Cultural Creatives (equivalent to postmoderns) [Ray, Anderson, 2000; Tibbs, 2011]. They have not been updated recently and should be judged with caution [Hines, 2015b].

- Traditional values have been around the longest and were prevalent for a great deal of human history but are declining in affluent countries (now at 25\%-30\% of the population).

- Modern values are peaking in affluent countries (35\%40\%) while they are surging in emerging markets.

- Postmodern values are growing in affluent countries (25\%-30\%).

- Integral values are just emerging in affluent countries (about 2\%)

The value types highlight patterns in preferences and priorities, but it should be noted that variations are more degrees of emphasis rather than either-or. For instance, postmoderns place a high priority on self-expression, but this does not mean that moderns or traditionals will not express themselves, it is just less important to them in general. For our purposes, the shift to postmodern and integral values is most relevant, as these are the newer types toward which values are moving. A key attribute of the postmoderns and integrals is "enoughness," which reflects a changing relationship between consumers and consumption. It is a sense that the consumption relationship needs to be reoriented such that consumption is not the end, but a means to various ends. While the postmoderns/integrals are relatively affluent, they are choosing to trade off money and material goods in exchange for time to enjoy experiences and invest in relationships. They are less concerned with status, recognition and collecting material goods and possessions. They are less inclined to put more time into their job in order to acquire more goods and services. The current key value proposition of

\footnotetext{
${ }^{5}$ For more details see: http://www.worldvaluessurvey.org/wvs.jsp, accessed 25.01.2019.
} 


\section{Four Values Types}

An individual view about what is most important in life that in turn guides decision-making and behavior

$\begin{array}{llll}\text { Follow the Rules } & \text { Achieve }\end{array}$

Source: author.

jobs - work more in order to be able to acquire the good things in life - has less appeal to those with postmodern and integral values [Hines, 2011].

Along those lines of shifting value priorities away from consuming and working more in order to consume more, the postmoderns/integrals are seeking greater "connection." They often report that their life feels out of control in the sense of their job dominating their lives. Many have the desire to connect or get reconnected with what is really important in their life. The chaos of daily life and the need to "keep up" has reached a point where people feel they have lost touch with their priorities. Thus they are seeking to scale back, focus, and enjoy those activities they are involved in and not feel like they are always rushing to the next thing. They want to spend more time with family and friends, get more involved in their community, know who their neighbors are, and who they do business with. In general, they want to become more re-engaged

\section{Figure 3. Blurring of Daily Life}

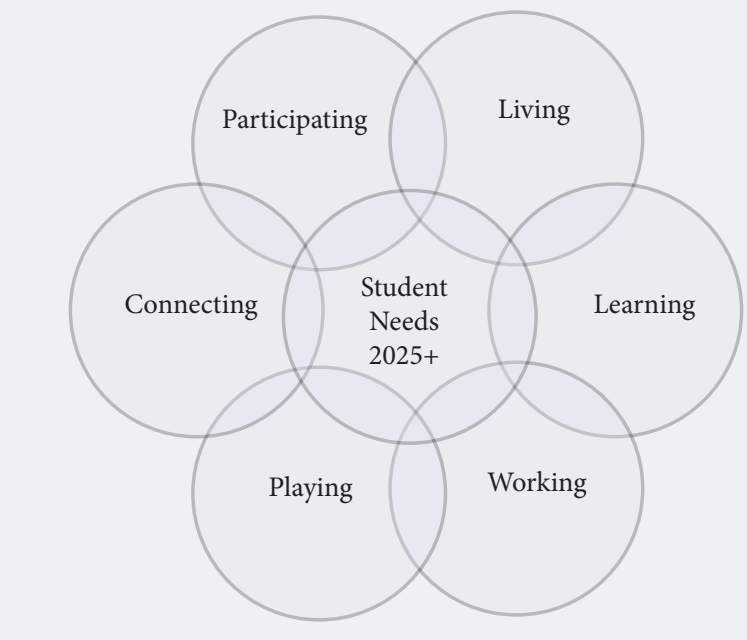

Source: author. with their daily lives. Thus, there is a search for a deeper purpose in one's life. This pursuit is seen as a worthy one that has intrinsic value and people want to tell the world about it [Hines, 2011].

These values shifts suggest a re-prioritization about what is really important in life. They suggest an opportunity for reconsidering the central importance of jobs and a desire for a more balanced life.

\section{The Blurring of the Boundaries of Daily Life}

Research into emerging student needs and the future of higher education from the perspective of the student identified "a shift in the purpose of higher education away from job preparation" as a plausible discontinuity ahead [Hines, 2017, 203]. A key supporting point for that discontinuity was the finding that the boundaries between various aspects of students daily lives was "blurring," that is, it will become increasingly difficult to precisely distinguish between the activities of daily life. Student daily life was organized into six activities: living, learning, working, playing, connecting, and participating [Houston Foresight, 2014] (see Figure 3, Table 3).

The research team concluded that the boundaries between all these aspects were blurring, such that it is and would continue to be increasingly difficult to pin down whether one is at play or working or learning and so on. Already studies suggest that the increasing blending of personal tasks at work is draining productivity - a 2015 estimate suggested that the US economy lost 50 million hours, or $\$ 7.4$ billion a day as a result [Gavett, 2015]. The blurring extends to multiple activities. For instance, during an author's class, students played a MOOG (Massively Open Online Game) exploring options for improving $\mathrm{R} \& \mathrm{D}$ in the future [Holden, 2013]. The team was learning (being in class), playing (having a lot of fun), working (client was using the team's input), and connecting (the team met dozens of other players among the thousands playing). In the future, it will be increasingly common to experience these moments where it is hard to classify or 
Table 3. Basic dimensions of daily life

\begin{tabular}{|l|l|}
\hline \multicolumn{1}{|c|}{ Dimension } & \multicolumn{1}{c|}{ Studied items } \\
\hline Living & $\begin{array}{l}\text { Focuses on changes in student consumption patterns, health, and housing, and investigates key changes in their } \\
\text { routine of daily life, such as how they might be spending their time differently in the future. }\end{array}$ \\
\hline Learning & $\begin{array}{l}\text { Focuses on how students might learn, whether within an institutional setting or not, and investigates major } \\
\text { changes in how they are acquiring the information and skills they need to get along in life. }\end{array}$ \\
\hline Working & $\begin{array}{l}\text { Focuses on the future job market and needs relating to work beyond just having a job, and investigates key changes } \\
\text { in how work is done. }\end{array}$ \\
\hline Playing & $\begin{array}{l}\text { Focuses on changes in student approaches to leisure, recreation, and having fun and investigates how playing in } \\
\text { general is changing. }\end{array}$ \\
\hline Connecting & $\begin{array}{l}\text { Focuses on changes in how students connect with one another, their friends, family, and colleagues - both real } \\
\text { and virtual - in the physical and online space, and investigates the changing means by which they do so. }\end{array}$ \\
\hline Participating & $\begin{array}{l}\text { Focuses on how students might participate differently in civic life and investigates what it means to be a citizen in } \\
\text { the future and how people interact with government and non-government groups. }\end{array}$ \\
\hline Source: compiled by the author using [Houston Foresight, 2014]. \\
\hline
\end{tabular}

explain what one is focused on at a particular moment. This is going to challenge traditional approaches to accounting for time on the job, i.e., should one "punch in" while playing an online game that may provide ideas for an innovative project at work? There are less clear distinctions between our activities - the days of going to a job focusing $100 \%$ on it from 9-5 are already gone for many.

For the purpose of this article, the key point is that work stands out less prominently as a separate and measurable activity and is more intertwined with other aspects of daily life. Given the lesser importance placed upon work and jobs, it was suggested that higher education might spend less time focusing on job preparation as a key mission.

\section{Obstacles}

The drivers above suggest that a transition to a post-work future is plausibly underway. It would be irresponsible, however, to suggest that this transition will be smooth or seamless. Such a transformational change as a post-work future will face many obstacles. Our research identified three key obstacles that could slow progress toward the post-work future, however, it is not likely that they will stop it. These key obstacles are [Hines, 2015a]:

- Jobs are central to an individual's identity

- Jobs provide structure to daily life

- Jobs are the primary source of income

Included with each description of an obstacle are suggestions on how it may be overcome.

\section{Jobs are Central to an Individual's Identity}

In many if not most cultures, people introduce or describe themselves to others principally in terms of the work they do; "So, what do you do?" is a common question one poses when exchanging names. Jobs are a significant component of who people are and not likely to change overnight. Biggs [Biggs, 2015] observes "work is ... how we give our lives meaning when religion, party politics and community fall away." Even if people do not like their jobs, it is often preferable to dealing with the powerful social stigma of unemployment. The shift to retirement from unemployment, for instance, brings about a significant increase in happiness [Frase, 2016].

The values shifts noted above toward jobs as less of a priority have been taking place over generations. The postmoderns now at roughly one-quarter of affluent populations have their roots in the 1960s counter-culture in the US more than two generations ago. The drivers above suggest it is likely that over time one's job will assume a more equal role among other components of one's identity.

- The values shifts suggest that individuals are rethinking priorities and what is really important in their life. Even if they love their jobs, the postmoderns and integrals in particular are attaching less importance to jobs for their sense of self. They value the work they do more than the job they have.

- The blurring trend suggests less relative importance being placed on jobs in one's daily life as the boundaries between work and play and learning become less defined.

\section{Jobs Provide Structure to Daily Life}

The bulk of work life is based around a Monday-to-Friday, nine-to-five schedule, around which other life activities must situate themselves [Kenton, 2018]. It was instituted as a standard practice in a range of industries seventyfive years ago in the US [Lebowitz, 2015]. It organized not only work, but society has' since organized "other activities" around it. For instance, graduate school classes for professionals are held in the evening. Religious ceremonies are typically held on weekends.

Jobs as the principle organizing structure of daily life is, however, being challenged. For many the traditional Monday-Friday nine-to-five schedule is already a distant memory. As work shifts out of the workplace to the home, coffee shops, and virtual spaces, people's daily routines have become less stable. Work has become more remote - 
a recent study found that 70 percent of professionals work remotely at least one day a week, while 53 percent work remotely for at least half of the week [Browne, 2015]. The free agent or gig economy model is already emerging [Friedman, 2014]. For those with skills in demand, this is often a choice to enable flexibility; for others it is often a necessity in which employers seek to avoid paying benefits and for minimizing the amount of time workers are on the payroll. Technological advances are enabling work to take place around the world and around the clock increasingly shifting the work to whenever it needs to be done rather than following a set schedule.

\section{Jobs are the Primary Source of Income}

Most people's ability "make a living" and gain access to society's wealth and resources are based upon the money earned from a job. It serves as the primary mechanism by which the economy distributes wealth. The US, for instance has full employment as a goal [Crook, 2018], while welfare and social programs for those not working are discouraged and minimized.

This role of jobs as income is likely to be the most difficult of the three to change. The paradigm of the existing economic order is focused upon full employment. Here, too, the US is likely to resist a shift away from this paradigm for political and ideological reasons. At the same time, just in the last few years, ideas such as a universal basic income are increasingly being discussed and small pilots are underway.

It would be foolish to suggest that the transition to a world where jobs go away or are significantly less important is going to be easy. However, there is already evidence that the three key roles that jobs play are already being challenged and chipped away. The transition is underway.

\section{What Can Be Done}

Futurists believe that a key purpose of exploring the longterm future is to identify what can be done to prepare for it in the present [Slaughter, 2015]. Amid the visions of a post-work future and the movement in that direction underway -albeit slow progress-it falls upon leaders, policymakers, employers, educators, and mentors to provide useful guidance on the long-term job future in the present. Three recommendations are offered to prepare for the post-work future and navigate the transition.

1. Advocate for a serious policy discussion on the postwork future

2. Develop programs to manage the transition

3. Promote the value of purpose and personal futures planning

\section{Advocate for a Serious Policy Discussion on the Post-Work Future}

A key role of futurists is to map out a range or landscape of plausible futures and help clients to develop an approach to that landscape. It is not practical or useful to attempt to predict the correct future. Unfortunately, much of the debate over the post-work future is likely to be a debate of whether and when it will happen. What is likely to be overlooked or ignored is developing a strategic approach to be prepared for it. Getting caught up in the will it/when will it happen debate is a distraction from the more useful work of preparing for it as well as other contingencies.

Ideally, a full range of social stakeholders, educators, policymakers, businesspeople, community representatives, and citizens are involved in the political discussion, whether via town halls, social media, or academic journals and conferences. For many people, a jobless future is likely to sound fanciful or scary.

A first task is to make it tangible and less frightening. People are tied to jobs for the reasons cited above, but for many the actual job itself is dreary and unfulfilling and unlikely to be missed. People naturally resist change. The real challenge of leaders is persuading people to come on a journey that involves change. It is necessary to paint a picture of where the change is going, and what the pathways might look like. Then one should suggest how that

Box 1. Community Purpose

Purpose could be explored at the community as well as individual level. At present, some communities or regions do economic development planning to promote their future. Often this involves trying to attract employers to come to the region. For instance, the goal is to get a major employer such as Amazon to relocate there and provide jobs, often by providing a package of incentives and breaks that end up mitigating the ultimate contribution.

Many rural areas in particular are undergoing an identity crisis, as previously big employers fold or leave, while the young people relocate to urban areas in search of opportunity. It raises questions about the purpose of the community. What might be a successful niche for a community or region in the emerging future? There are stories of both urban and rural areas that have revitalized, but very often this is along the lines of refashioning the economy to attract employers and jobs. In the post-work future, that strategy is less practical. I think communities themselves also need a purpose now. How do you want people to experience living here? 
change could be favorable - or not. This will move the post-work from an intangible possibility to a tangible one and create a sense of opportunity instead of generating fear of the unknown.

\section{Develop Programs to Manage the Transition}

It is difficult to know at this point what programs make sense to develop, given the lack of understanding and discussion about the post-work future. Two types of programs are suggested here: exploratory and practical.

Exploratory programs would have learning as their primary purpose. They might be pilots or research projects aimed at particular aspects of the post-work future. There are already pilots and small-scale programs dealing with aspects of the post-work future underway, such as UBI (universal basic income) trials noted above. These programs provide value learning and experience. They are still largely operating on the fringes of most societies, who are woefully unprepared for this future. Some examples include:

- Piketty [Piketty, 2014] suggests a progressive global tax on capital as a redistributive mechanism. India's Congress party recently hired him to explore a minimum income guarantee program.

- A "universal dividend" approach has been proposed, which argues that wealth is generated collectively and should then be privatized via the distribution of a dividend [Parkins, 2017].

- Several different approaches to UBI have been suggested. For example, in a three-year pilot funded by the provincial government, about 4,000 people in Ontario are receiving monthly stipends to boost them to at least $75 \%$ of the poverty line [Bergstein, 2018].

- The ILO’s (International Labor Organization) Global Commission on the Future of Work advocates a Universal Labour Guarantee, which stipulates social protection from birth to old age and an entitlement to lifelong learning [ILO, 2019].

- UCL's Institute for Global Prosperity suggests universal basic services (instead of UBI) including access to mobile and internet, housing, food, and transport at a cost of 2\% or so of GDP per annum [Painter, 2017].

- Finally, shifting way from GDP as the key measure of progress would help shift the focus away from work. The GPI (Genuine Progress Indicator) takes dozens of factors into account besides GDP [Bollier, 2014].

The practical type of programs would help jobholders deal with the more frequent and extended periods where they are out of work. The objective would be not only to deal with income and benefits issues, but also to start the transition to a post-work future. Dealing with the practical issues of income, health insurance, and retraining would enable people to experiment with developing new interests and new ways of living that would be increasingly useful and common in the post-work future. Some examples include.
- Experiment with programs to redesign the K-12 curriculum to meet the changing nature of work and the post-work future. The redesign should prepare learners continually to reskill and upskill and to know how to partner constructively with machines. The objective is teaching student core social-emotional skills that will provide the basics for building effective work practices, learning strategies, and career development approaches that will lead to success in academic pursuits, work, and life [Prince et al., 2017]

- A recent World Bank [World Bank, 2019, 72] report advocated supporting tertiary education programs defined as any education beyond the high school level, including trade schools and college - and observed that "the demand is growing for transferable higher-order cognitive skills such as logic, critical thinking, complex problem-solving, and reasoning."

- Support programs to continue retraining and upskilling outside of school. Investment in workplace training is often neglected. The US, for example, spends on $0.2 \%$ of its GDP on labor market programs, which is the lowest of any of the OECD countries. [Gaskell, 2019].

- Support entrepreneurs and small business with in vestment from the public sector and trade associations [Ready, 2018].

- Make reducing the work week a social priority by gradually reducing hours in line with increases in productivity, so that people could gradually work less and less [Frase, 2016].

- As we move into the gig economy, there will be opportunities to support workers in between gigs, such as providing health insurance for these gaps. For many, living through insecure jobs interspersed with periods of unemployment or labor-force withdrawal is a huge issue [Standing, 2014].

\section{Emphasize a Holistic Approach to Finding Purpose and Meaning in Life}

As noted above, the role of jobs has been central to the identity of individuals and the functioning of society and the economy. Jobs have provided a sense of purpose. In a future where jobs are less important, it will create a gap or a new search for purpose. There is some fear that without jobs, people will not know what to do with themselves. There is an opportunity now to begin educating, training, and helping people to find purpose. It is also noted above that there is still work to be done, so that can still provide purpose.

Developing that sense of purpose is not easy and it is just the beginning. In our graduate school curriculum, we teach so-called personal futures planning and it is basically taking the same principles that are used with organizations or government agencies, whoever it might be that we are working with. While it is a good thing to do at any lifestage, in terms of what can be done immediately, it 
would make sense to advocate for personal futures planning as a lifelong activity, beginning in $\mathrm{K}-12$.

Having a sense of purpose and a sense of direction from the personal futures planning really helps when it comes to those pivotal life choices. Some of this personal planning goes on today, but it is typically narrowly focused. For instance guidance counselors offer advice about which track to take, vocational or college, aimed at finding a career. A key opportunity is to expand upon the notion of career planning to life planning [Wheelwright, 2010]. The notion of a career may come to be seen as limiting. Rather than preparing for a job or a career, it can help clients prepare for life, of which work is a single piece. At the same time, it is a disservice to stop there and suggest that people simply wait for the transformation. They must live through the transition and right now that means jobs are important.

\section{Conclusions}

This paper explored the possibilities for a post-work future with the intention of stimulating interest in beginning to prepare for it. It recognizes that such a future may be decades away, but suggests that the magnitude of such a transformation is large enough to begin serious planning today.

Our research resulted in the design of three plausible longterm visions of a post-work future without the centrality of jobs for which would be reasonable to begin preparing. These visions are - Tech-Led Abundance, Non-Workers' Paradise, and the Sustainable Commons. The three key drivers already pushing toward a post-work future are: rise of automation, AI, machine intelligence moving toward a future where people are less necessary for work; shifts in individual values toward postmodern and integral values that place less emphasis on material goods accumulation and working towards that end; and the blurring of daily activities, such that work becomes increasingly indistinguishable from other activities and becomes less of a cen- tral factor. Also, there are significant obstacles to a postwork future, which are determined by the central role of work in social life. Jobs are central to an individual's identity, but are slowly becoming less significant. Jobs provide structure to daily life, but the structure of daily life itself is being challenged by changes in technology and the economy. Jobs are a primary source of income, but alternative mechanisms are slowing emerging.

Thus, even though these obstacles are being addressed it may take decades for this transition to occur. Despite this, the transition is going to create challenges such that it makes sense to prepare now. Among the sensible measures that are supported by a numerous pieces of evidence are:

- Advocate for a serious policy discussion on the postjobs future.

- Develop programs to manage the transition.

- Promote the value of purpose and personal futures planning.

The limitations of the paper are inherent in its speculative nature. For the sake of brevity suitable to journal articles, while making a case that a post-work future is plausible, we do not compare it with other equally or perhaps even more plausible futures. Moreover, when making the cases for the plausibility of a post-work future we rely on a few key factors while recognizing that several others may be equally influential.

Several promising area for future research stand out:

- Identify and evaluate comprehensive visions of a post-work future (underway).

- Map plausible pathways to these visions.

- Monitor the progress of various experiments, trials, and pilots.

In closing, it is critical to remember that a post-work future does not mean that people will run out of useful things to do, but rather that they will not require jobs in order to be useful.

\section{References}

Alperovitz G. (2013) The possibility of a pluralist commonwealth and a community sustaining political-economic system. The Pluralist Commonwealth. Available at: http://www.pluralistcommonwealth.org/possibility-of-pc.html, accessed 25.01.2019.

Anzilotti E. (2019) The one clear result of Finland's basic income trial: It made people happier. Fast Company, 20.02.2019. Available at: https://www.fastcompany.com/90308392/the-one-clear-result-of-finlands-basic-income-trial-it-made-people-happier, accessed 26.02.2019.

Armstrong P. (2017) Which one of these will be your job title in 2037? Fortune Blog, 21.09.2017. Available at https://www.forbes.com/ sites/paularmstrongtech/2017/09/21/which-one-of-these-will-be-your-job-title-in-2037/\#64eade9549f8, accessed 25.01.2019.

Beck D., Cowan C. (2005) Spiral dynamics: Mastering values, leadership and change, Hoboken, NJ: Wiley-Blackwell.

Bergstein B. (2018) Basic income could work - if you do it Canada-style. MIT Technology Review, 20.06.2018. Available at: https://www. technologyreview.com/s/611418/basic-income-could-work-if-you-do-it-canada-style/, accessed 25.01.2019.

Biggs J. (2015) All day long: A portrait of Britain at work, London: Serpent's Tail.

Bollier D. (2014) Think like a commoner: A short introduction to the life of the commons, Gabriola Island, BC, Canada: New Society Publishers. 
Bostrom N. (2014) Superintelligence: Paths, dangers, strategies, Oxford, UK: Oxford University Press.

Brown E. (2018) Universal Basic Income is Easier than It Looks. Truthdig, 27.12.2018. Available at: https://www.truthdig.com/articles/ universal-basic-income-is-easier-than-it-looks/, accessed 25.01.2019.

Browne T. (2018) 70\% of people globally work remotely at least once a week, study says. CNBC Make It, 30.05.2018. Available at: https://www.cnbc.com/2018/05/30/70-percent-of-people-globally-work-remotely-at-least-once-a-week-iwg-study.html, accessed 25.01.2019.

Brynjolfsson E., McAfee A. (2014) The second machine age: Work, progress, and prosperity in a time of brilliant technologies, New York: W.W. Norton \& Company.

CASSE (n.d.) What is a Steady State Economy? (Center for the Advancement of the Steady State Economy (CASSE) Brief). Available at: http://www.steadystate.org/wp-content/uploads/CASSE_Brief_SSE.pdf, accessed 25.01.2019.

Coelho A. (2019) India: Congress party gets serious about basic income and reaches out to Thomas Piketty for policy design support. BIEN (Basic Income Earth Network), 14.02.2019. Available at: https://basicincome.org/news/2019/02/india-congress-party-getsserious-about-basic-income-and-reaches-out-to-thomas-piketty-for-policy-design-support/, accessed 26.02.2019.

Crook C. (2018) Full Employment. Bloomberg, 06.07.2018. Available at: https://www.bloomberg.com/quicktake/full-employment, accessed 25.01.2019.

De Angelis M. (2017) Omnia sunt communia: On the commons and the transformation to postcapitalism, London: Zed Books.

De Wispelaere J., Halmetoja A., Ville-Veikko P. (2018) The Finnish basic income experiment - correcting the narrative. Social Europe, 08.11.2018. Available at: https://www.socialeurope.eu/the-finnish-basic-income-experiment-correcting-the-narrative, accessed 25.01.2019.

Diamandis P. (2012) Abundance: The future is better than you think, New York: Simon \& Schuster.

Diamond M. (2019) This 2020 candidate puts his money on universal income. Real Clear Politics, 20.02.2019. Available at: https:// www.realclearpolitics.com/articles/2019/02/20/this_2020_candidate_puts_his_money_on_universal_income_139516.html, accessed 20.02.2019.

Eisenstein C. (2011) Sacred economics: Money, gift, and society in the age of transition, Berkeley, CA: North Atlantic Books.

EMF (2013) Towards the circular economy: Economic and business rationale for an accelerated transition, vol. 1, Cowes, UK: Ellen MacArthur Foundation. Available at: https://www.ellenmacarthurfoundation.org/assets/downloads/publications/Ellen-MacArthurFoundation-Towards-the-Circular-Economy-vol.1.pdf, accessed 25.01.2019.

Fioramonti L. (2016) Well-being economy: A scenario for a post-growth horizontal governance system. The Next System Project Website, 03.11.2016. Available at: https://thenextsystem.org/well-economy-scenario-post-growth-horizontal-governance-system, accessed 25.01.2019.

Frase P. (2016) Four futures: Life after capitalism, New York: Verso Books.

Frey C., Osborne M. (2013) The Future of Employment: How Susceptible are Jobs to Computerisation? (Working Paper, Oxford Martin Programme on Technology and Employment), Oxford: Oxford University Press. Available at: https://www.oxfordmartin.ox.ac.uk/ downloads/academic/future-of-employment.pdf, accessed 19.02.2019.

Frey T. (2011) 55 Jobs of the Future, Business Trends. Futurist Speaker, 11.11.2011. Available at: https://futuristspeaker.com/businesstrends/55-jobs-of-the-future/, accessed 25.01.2019.

Friedman G. (2014) Workers without employers: Shadow corporations and the rise of the gig economy. Review of Keynesian Economics, vol. 2, no 2, pp. 171-188.

Galeon D. (2019) Separating Science Fact From Science Hype: How Far off Is the Singularity? Futurism, 30.01.2018. Available at: https:// futurism.com/separating-science-fact-science-hype-how-far-off-singularity, accessed 19.02.2019.

Gaskell A. (2019) Humans remain central to the future of work. RealKM, 17.02.2019. Available at https://realkm.com/2019/02/17/ humans-remain-central-to-the-future-of-work/, accessed 26.02.2019.

Gavett G. (2015) Workers are bad at filling out timesheets, and it costs billions a day. Harvard Business Review, 12.01.2015. Available at: https://hbr.org/2015/01/workers-are-bad-at-filling-out-timesheets-and-it-costs-billions-a-day, accessed 20.02.2019.

Gibbs S. (2017) Uber plans to buy 24,000 autonomous Volvo SUVs in race for driverless future. The Guardian, 20.11.2017. Available at: https://www.theguardian.com/technology/2017/nov/20/uber-volvo-suv-self-driving-future-business-ride-hailing-lyft-waymo, accessed 20.02.2019.

Greene T. (2017) Google's AI guru predicts humans and machines will merge within 20 years. The Next Web, 10.11.2017. Available at: https://thenextweb.com/artificial-intelligence/2017/11/10/googles-ai-guru-predicts-humans-and-machines-will-merge-within-20years/, accessed 19.02.2019.

Groshen E., Helper S., MacDuffie J.P., Carson C. (2018) Preparing U.S. workers and employers for an autonomous vehicle future (Report prepared for SAFE - Securing America's Energy Future), Washington, D.C.: SAFE. Available at https://avworkforce.secureenergy.org/ wp-content/uploads/2018/06/Groshen-et-al-Report-June-2018-1.pdf, accessed 25.01.2019.

Haque U. (2011) Betterness: Economics for Humans, Cambridge, MA: Harvard Business Review Press.

Hines A. (1993) Transferable skills land future jobs. HR Magazine, vol. 38, no 4, pp. 55-56.

Hines A. (1996) Jobs and infotech: Work in the information society. Exploring your future: Living, learning, and working in the information age (ed. E. Cornish), Bethesda, MD: World Future Society, pp. 7-11. 
Hines A. (2011) Consumer Shift: How Changing Values are Reshaping the Consumer Landscape, Tucson, AZ: No Limit Publishing.

Hines A. (2013) After Capitalism. Hinesight, 15.10.2013. Available at: https://www.andyhinesight.com/category/after-capitalism/, accessed 25.01.2019.

Hines A. (2015a) The end of work as we know it. Career Planning and Adult Development Journal, Summer issue, pp.10-19.

Hines A. (2017) Emerging student needs disrupting higher education. On the Horizon, vol. 25, no 3, pp. 197-208.

Hines A., Bengston D., Dockry M., Cowart A. (2018) Setting up a horizon scanning system: A U.S. federal agency example. World Futures Review, vol. 10, no 2, pp. 136-151.

Hines A., Bishop P. (2013) Framework foresight: Exploring futures the Houston way. Futures, vol. 51, pp. 31-49.

Hines, A. (2015b) Future-friendly design: Designing for and with future consumers. Design thinking: New product development essentials from the PDMA (eds. M. Luchs, K.S. Swann, A. Griffin), Hoboken, NJ: Wiley, pp. 333-348.

Holden G. (2013) Innovate2038: Envisioning the future of R\&D with global crowd-sourcing. Flashpoint: The Official Blog of Innovation Research Interchange, 27.09.2013. Available at https://iriwebblog.org/2013/09/27/innovate2038-envisioning-the-future-of-rd-withglobal-crowd-sourcing/, accessed 25.01.2019.

Houston Foresight Program (2014) The future of student needs: 2025 and beyond, Indianapolis, IN: Lumina Foundation. Available at: https:/www.houstonforesight.org/wp-content/uploads/2015/05/FutureStudentNeeds2025LR.pdf, accessed 25.01.2019.

Houston Foresight Program (2017) The future of work 2050 for NASA LARC, Houston, TX: University of Houston. Available at: https:// www.houstonforesight.org/wp-content/uploads/2017/10/NASA-LaRC-Future-of-Work-White-Paper.pdf, accessed 25.01.2019.

ILO (2019) Work for a Brighter Future (Report by the Global Commission on the Future of Work), Geneva: International Labor Organization.

Inglehart R. (2018) Cultural Evolution, Cambridge: Cambridge University Press.

Jackson T. (2009) Prosperity without growth? Economics for a finite planet, London: Earthscan.

Kallis G., Demaria F., D’Alisa G. (2015) Introduction: Degrowth. Degrowth: A vocabulary for a new era (eds. G. D’Alisa, F. Demaria, G. Kallis) (1st ed.), New York: Routledge.

Kenton W. (2018) Business day. Investopedia, 21.02.2018. Available at https://www.investopedia.com/terms/b/business-day.asp, accessed 25.01.2019.

Kurzweil R. (2005) The singularity is near: When humans transcend biology, New York: Penguin.

Lebowitz S. (2015) Here's how the 40-hour workweek became the standard in America. Business Insider, 24.10.2015. Available at: https:// www.businessinsider.com/history-of-the-40-hour-workweek-2015-10, accessed 25.01.2019.

Leopold T., Stefanova V., Zahidi R. (2018) The Future of Jobs Report 2018, Geneva: World Economic Forum.

Loh P., Jimenez S. (2017) Solidarity Rising in Massachusetts: How Solidarity Economy Movement Is Emerging in Lower-Income Communities of Color, Boston, MA: TSNE. Available at http://tsne.org/downloads/SEI_SolidarityRising_Final.pdf, accessed 25.01.2019.

Mason P. (2015) Postcapitalism: A guide to our future, New York: Farrar, Straus \& Giroux.

Minder R. (2016) Guaranteed income for all? Switzerland's voters say no thanks. New York Times, 05.06.2016. Available at: https://www. nytimes.com/2016/06/06/world/europe/switzerland-swiss-vote-basic-income.html, accessed 20.02.2019.

More M. (2013) The philosophy of transhumanism. Transhumanist Reader: Classical and Contemporary Essays on the Science, Technology, and Philosophy of the Human Future (eds. M. More, N. Vita-More), Hoboken, NJ: Wiley-Blackwell, pp. 1-17.

Painter A. (2017) Universal basic services or universal basic income? RSA (Royal Society for the encouragement of Arts, Manufactures and Commerce), 17.10.2017. Available at: https://www.thersa.org/discover/publications-and-articles/rsa-blogs/2017/10/universal-basicservices-or-universal-basic-income, accessed 26.02.2019.

Parkins K. (2017) Universal fividend. Medium, 11.02.2017. Available at: https://medium.com/dark-mountain/universal-dividenda988c31c372b, accessed 26.02.2019.

Piketty T. (2014) Capital in the twenty-first century, Cambridge, MA: Belknap Press.

Prince K., Saveri A., Swanson J. (2017) The future of learning: Redefining readiness from the inside out, Cincinnati: Knowledge Works.

Ray P.H., Anderson S.R. (2000) The Cultural Creatives: How 50 Million People Are Changing the World, New York: Harmony Books.

Ready B. (2018) How small companies can compete on the world stage. Paper presented at the World Economic Forum Annual Meeting 23-26 January 2018, Davos-Klosters, Switzerland. Available at: https://www.weforum.org/agenda/2018/01/how-small-companiescan-compete-on-the-world-stage/, accessed 26.02.2019.

Reese B. (2019) AI will create millions more jobs than it will destroy. Here's how. Singularity Hub, 01.01.2019. Available at https:// singularityhub.com/2019/01/01/ai-will-create-millions-more-jobs-than-it-will-destroy, accessed 26.02.2019.

Rifkin J. (2014) The zero marginal cost society: The internet of things, the collaborative commons, and the eclipse of capitalism, New York: St. Martin's Press.

Scharmer O. (2013) Leading from the emerging future: From ego-system to eco-system economies, San Francisco: Berrett-Koehler.

Schweickart D. (2011) After capitalism (2nd ed.), Lanham, MD: Rowman \& Littlefield.

Sherman E. (2018) AI is the new face of systemic (and automated) inequality. Forbes, 11.10.2018. Available at: https://www.forbes.com/ sites/eriksherman/2018/10/11/ai-is-the-new-face-of-systemic-and-automated-inequality/\#2ff86e191838, accessed 19.02.2019. 
Slaughter A., Bahat R., Sharp K. (2016) Shift: The commission on work, workers, and technology, Washington, D.C.: New America, Bloomberg.

Slaughter R. (2015) Preface. Thinking about the future (eds. A. Hines, P. Bishop) (2 $2^{\text {nd }}$ ed.), Houston, TX: Hinesight.

Slayter M.E. (2019) 11 really cool jobs that don't exist today, but will soon. Monster Blog. Available at https://www.monster.com/careeradvice/article/cool-future-jobs, accessed 25.01.2019.

Snow J. (2018) Algorithms are making American inequality worse. MIT Technology Review, 26.01.2018. Available at: https://www. technologyreview.com/s/610026/algorithms-are-making-american-inequality-worse/, accessed 19.02.2019.

Srnicek N., Williams A. (2016) Inventing the future: Postcapitalism and a world without work, Brooklyn, NY: Verso Books.

Standing G. (2014) A precariat charter: From denizens to citizens, New York: Bloomsbury Publishing.

Standing G. (2018) Why the world should adopt a basic income. The Economist, 04.07.2018. Available at https://www.economist.com/ open-future/2018/07/04/why-the-world-should-adopt-a-basic-income?fsrc=gp_en, accessed 25.01.2019.

Talwar R., Hancock T. (2010) The shape of jobs to come, London: Fast Future.

Thorpe E.K. (2018) Gartner: By 2020, AI will create more jobs than it eliminates. ITPRPO, 05.02.2018. Available at https://www.itpro. co.uk/automation/30463/gartner-by-2020-ai-will-create-more-jobs-than-it-eliminates, accessed 19.02.2019.

Tibbs H. (2011) Changing cultural values and the transition to sustainability. Journal of Futures Studies, vol. 15, no 3, pp. 13-32.

Toffler A. (1980) The third wave, New York: Morrow.

Vita-More N. (2018) Transhumanism: What is it?, New Providence, NJ: Bowker.

WCED (1987) Our Common Future (World Commission on Environment and Development Report), Oxford: Oxford University Press.

Wheelwright V. (2010) It's your future... make it a good one!, Harlingen, TX: Personal Futures Network.

World Bank (2019) World development report 2019: The changing nature of work, Washington, DC: World Bank. 